\title{
PELATIHAN PEMBUATAN MEDIA VIDEO PROMOSI PENJUALAN DODOL DI DESA LAMA HAMPARAN PERAK
}

\author{
${ }^{1}$ Dani Manesah, ${ }^{2}$ Muhammad Ali Mursid Alfathoni \\ 1,2 Universitas Potensi Utama, Medan, Sumatera Utara \\ Email: manesahh@gmail.com
}

(Diterima: 6 September 2021; Direvisi: 25 Oktober 2021; Dipublikasikan: November 2021)

\begin{abstract}
Abstrak
Desa Lama terletak pada salah satu Kecamatan Hamparan Perak, Kabupaten Deli Serdang Provinsi Sumatera Utara. Kegiatan yang dilakukan oleh Bapak Sabarudin dan beberapa anggota yang terdapat di Desa Lama Hamparan Perak yaitu memproduksi makanan tradisional berjenis dodol. Meskipun hanya makanan tradisional namun makanan tersebut tidak kalah bersaing ditengah makanan yang populer di tengah-tengah masyarakat. Namun terdapat salah satu masalah yaitu terkait promosi yang dilakukan oleh Bapak Sabarudin dan anggota, masih menggunakan cara manual dan hanya dilakukan dari mulut ke mulut saja. Metode yang digunakan dalam pengabdian ini yaitu melakukan observasi, interview, pendekatan dan pelatihan. Tujuan dari pengabdian ini untuk memudahkan dalam proses pelaksanaan pengabdian masyarakat dalam pembuatan video promosi. Tahapan pelaksanaan kegiatan dimulai dari tahap persiapan pelaksanaan, dan evaluasi yang berfokus pada keterampilan dalam membuat sebuah promosi penjualan menggunakan media video. Sementara hasil yang didapat dalam kegiatan dan pelatihan pemanfaatan media video sebagai sarana promosi yaitu untuk meningkatkan penyerapan dan pemasukan bagi Bapak Sabarudin dan anggota. Sebelum diadakan pelatihan ini promosi dodol hanya melalui mulut ke mulut. Kegiatan pengabdian masyarakat ini bermanfaat bagi pelaku usaha pembuatan dodol di Desa Lama Kecamatan Hamparan Perak.
\end{abstract}

Kata Kunci: Desa Lama, Dodol, Promosi, Sabarudin

\begin{abstract}
:
Old Village is located in one of the Districts of Hamparan Perak, Deli Serdang Regency of North Sumatra Province. The activities carried out by Mr. Sabarudin and some members in the Old Village of Hamparan Perak are producing traditional dodol-type food. Although only traditional food but the food is no less competitive amid popular food in the community. But there is one problem that is related to the promotion carried out by Mr. Sabarudin and members, still using manual methods and only done by word of mouth only. The methods used in this devotion are observation, interview, approach and training. With the application of these methods aims to facilitate in the process of community service implementation in the creation of promotional videos. The implementation stage of the activity starts from the preparation stage of implementation, and evaluation that focuses on skills in making a sales promotion using video media. The results obtained in activities and training in the use of video media as a means of promotion are to increase absorption and income for Mr. Sabarudin and members. Before this training was held the promotion of dodol was only by word of mouth. This community service activity is useful for dodol making business actors in the Old Village of Hamparan Perak Subdistrict.
\end{abstract}

Keywords: Old Village, Dodol, Promotion, Sabarudin 


\section{PENDAHULUAN}

Audio visual merupakan media yang memiliki dua unsur yaitu unsur suara dan gambar. Media ini memiliki kemampuan yang lebih baik karena meliputi suara dan gambar. Media audio visual merupakan media yang dapat digunakan untuk menyampaikan pesan pembelajaran dan sebagainya. Dalam media audio visual kedua unsur tersebut saling bersatu. Adanya unsur audio dapat memudahkan orang untuk dapat menerima pesan pembelajaran melalui pendengaran, sedangkan unsur visual tentunya pendengar dapat melihat dan menerima pesan melalui visual. (Khoerunnisa, Anis et all. Media Audio Visual Makalah 2012). Selain dalam pengertian tersebut Audio visual sendiri dapat juga dijadikan sebagai ajang promosi, salah satu nya yaitu promosi makanan atau jenis lainnya. Dikarenakan promosi merupakan kegiatan penting dan memiliki peran yang sangat aktif dalam mempromosi suatu produk kepada konsumen agar mendorong konsumen untuk membeli produk yang dipromosikan (Wasan \& Sariningsih, 2021). Untuk mempromosikan sebuah produk, dapat memanfaatkan media online berbasis website sebagai fasilitas dalam penjualan atau promosi produk kepada konsumen (Haryadi et al., 2021)

Di Dalam sektor perdagangan terdapat masih banyak komoditas ataupun barang dagangan yang berpotensi belum ditangani dengan serius dalam mempromosikannya. Hal tersebut tentu menjadi salah satu ancaman bagi para produsen, terutama produsen makanan tradisional di dalam mempertahankan sebuah produk yang mereka produksi. Salah satu cara agar makanan tradisional tetap dikenal dan tidak punah adalah dengan tetap memproduksinya serta mempromosikannya. Seseorang akan tetap memproduksi barang maupun jasa jika dianggap dapat memberikan keuntungan dan mampu meningkatkan pendapatan (Herlina et al., 2021). Adapun jenis makanan tradisional yang diproduksi oleh Bapak Sabarudin adalah dodol, dimana dodol merupakan jenis makanan tradisional yang cukup populer di beberapa daerah salah satunya berada di Kecamatan Hamparan Perak, tepatnya di Desa Desa Lama. Kampung Lama ataupun dapat disebut juga dengan sebutan Desa Lama merupakan salah satu desa yang terdapat pada Kecamatan Hamparan Perak, Kabupaten Deli Serdang, Provinsi Sumatera Utara, Indonesia. Penduduk asli dari Desa Lama tersebut adalah melayu deli sebanyak $65 \%$, dan suku pendatang jawa sebanyak $30 \%$ serta batak, banjar, padang sebanyak $5 \%$.

Dodol tersebut memiliki sebuah prospek yang cerah serta dapat dikembangkan dengan berbagai variasi rasa karena dalam pencarian bahan baku untuk pembuatannya masih tersedia secara lokal. Namun dalam pengelolaan nya, usaha dodol yang dilakukan oleh Bapak Sabarudin serta proses pembuatan dan promosinya masih dilakukan secara tradisional, seperti dari mulut ke mulut, sehingga menyebabkan kapasitas dalam produksinya masih tergolong rendah, biaya untuk produksi memakan biaya yang cukup tinggi, dan sebagainya (Goenawan et al., 2013). Jamaludin mengatakan bahwa kegiatan promosi merupakan bentuk dari sarana komunikasi antara produsen dan konsumen untuk memperkenalkan produk, baik dari segi jenis, warna, bentuk, harga, maupun kualitas produk yang ditawarkan atau yang dihasilkan oleh perusahaan (Jamaludin, 2015). Senada dengan perkataan tersebut Swastha juga mengatakan bahwasanya promosi adalah sebuah informasi yang berupa tindakan penukaran dan pembelian yang disebarkan lewat media promosi. Pada dasarnya promosi merupakan salah satu bentuk usaha yang dilakukan untuk menyebar informasi yang bertujuan untuk mengajak konsumen untuk membeli sebuah produk (Kurniawan \& Wahyurini, 2017). Selain itu, dapat dikatakan bahwa promosi adalah bentuk pertukaran informasi dalam bentuk dua arah antara pihak-pihak yang terlibat dalam promosi tersebut (Swastha \& others, 2005)

Pemilihan media promosi dengan menggunakan media audio visual disebabkan karena sebelumnya pembuatan dodol belum pernah melakukan promosi menggunakan 
media audio visual atau video. Salah satu keunggulan dari media audio visual adalah memiliki jangkauan yang sangat luas, dan mampu menyesuaikan dengan perkembangan teknologi zaman jika disebar melalui jaringan internet dengan memanfaatkan media sosial. Dimana sekarang adalah zamannya internet dan gadget, sehingga dengan adanya pembuatan media promosi berbentuk video ini akan lebih praktis serta dapat dinikmati dan dapat diaplikasikan melalui media sosial tanpa ada batas waktu. Dengan adanya permasalahan tersebut peneliti memberikan sebuah solusi terkait media promosi yaitu dengan mengadakan sebuah pelatihan tentang tentang bagaimana pembuatan media promosi terkait penjualan dodol yang dilakukan oleh Bapak Sabarudin dan anggota melalui sebuah video.

\section{METODE}

Dalam kegiatan pengabdian masyarakat yang dilakukan dalam bentuk pelatihan pembuatan media video promosi penjualan dodol di desa lama hamparan perak. Penulis melakukan beberapa metode dalam strategi dalam rangka menyelesaikan permasalahan dapat dilihat pada gambar dibawah ini.

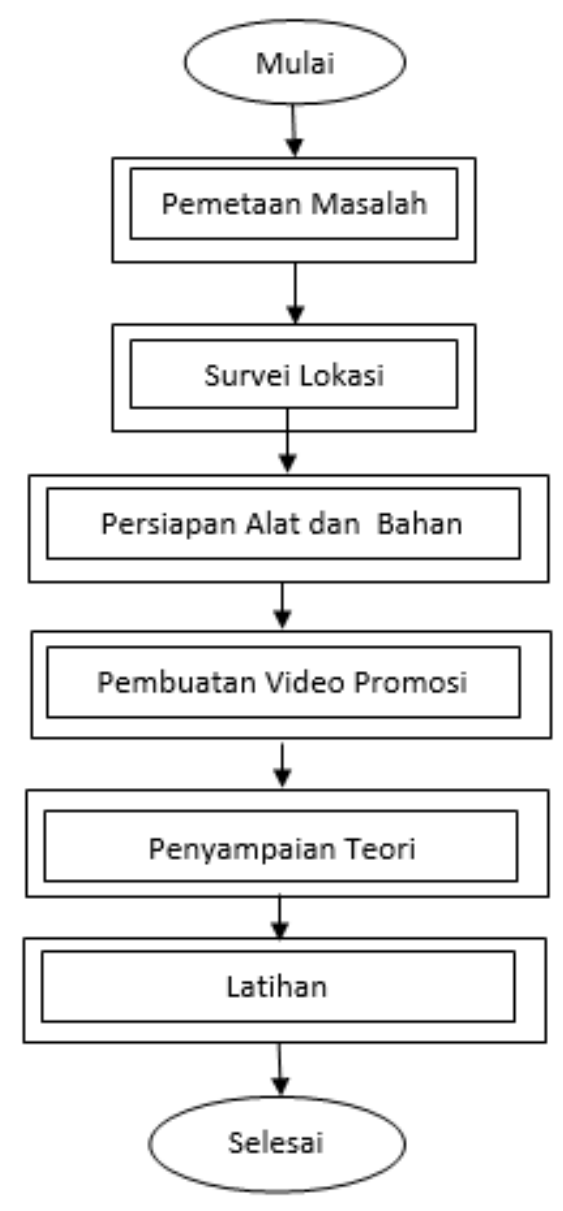

Gambar 1. Flowchart Pengabdian Kepada Masyarakat Terhadap Pelatihan Pembuatan Media Promosi Penjualan Dodol

Beberapa metode yang dilakukan dalam kegiatan pengabdian kepada masyarakat adalah sebagai berikut:

a. Observasi 
Observasi yang dilakukan oleh penulis adalah pencarian lokasi pelaku usaha pembuatan dodol yang terdapat di Kecamatan Hamparan Perak yang berlokasi di Desa Lama. Menurut Abdurrahman observasi merupakan sebuah teknik pengumpulan data yang dapat dilakukan melalui pengamatan, yang disertai dengan pencatatan-pencatatan terhadap keadaan atau perilaku objek sasaran (Fathoni, 2006). Senada dengan pengertian tersebut Nana Sudjana menambahkan bahwa observasi adalah proses pengamatan maupun pencatatan yang sistematis terhadap suatu gejala yang diteliti (Sudjana, 2020).

b. Interview / Wawancara

Interview / Wawancara setelah melakukan observasi kepada pelaku usaha pembuatan dodol, langkah selanjutnya penulis melakukan proses wawancara kepada pemilik pembuatan usaha dodol yaitu Bapak Sabarudin, dalam proses pewawancaraan tersebut penulis menanyakan bagaimana proses penjualan yang dilakukan oleh Bapak Sabarudin dan anggota dalam memasarkan produk nya.

c. Pendekatan

Pendekatan penulis lakukan guna memberi himbauan kepada Bapak Sabarudin dan anggota tanpa adanya unsur paksaan, bagi anggota agar dapat ikut berperan aktif dalam proses pelaksanaan dalam kegiatan pengabdian masyarakat ini. Penulis berupaya agar seluruh anggota termotivasi dalam proses pembuatan media video promosi dalam kegiatan pengabdian kepada masyarakat ini.

Setelah melakukan identifikasi terhadap bentuk pelatihan pembuatan media video promosi penjualan dodol di desa lama hamparan perak, selanjutnya penulis melakukan kegiatan pelatihan terhadap pembuatan media video promosi sebagai berikut :

a. Materi Pendidikan kepada anggota

Pendidikan ini bertujuan guna menambah wawasan serta pengetahuan terhadap pembuatan media video promosi penjualan. Selain itu, materi ini dilakukan untuk memberikan motivasi kepada para anggota yang terlibat dalam kegiatan pengabdian ini.

b. Pelatihan

Pelatihan ini dilakukan dengan praktek penggunaan kamera dalam mengambil gambar agar terkesan lebih estetik, guna menambah minat pembeli dodol tersebut. Materi inti dilakukan sesuai dengan identifikasi awal yaitu promosi terhadap penjualan masih dilakukan secara manual.

\section{HASIL dan PEMBAHASAN}

Pengabdian Pada Masyarakat yang penulis lakukan di Kecamatan Hamparan Perak tepatnya di Desa Lama Kabupaten Deli Serdang. Pengabdian ini menemukan hasil bahwa pembuatan dan pemasaran dodol yang dilakukan oleh Bapak Sabarudin dan anggotanya dilakukan secara manual. Ketika dodol selesai diproduksi dodol akan dikemas oleh Bapak Sabarudin dan anggotanya untuk dipasarkan ke konsumen. Teknik pemasaran dilakukan dengan cara meletakkan dodol yang sudah dikemas ke warung-warung terdekat yang sudah ada perjanjian yang disepakati. Selain itu, pemasaran dodol juga dilakukan mulut ke mulut. Dengan demikian dodol yang diproduksi oleh Bapak dan Anggota dikenal oleh masyarakat ramai. Selain itu, dodol produksi Bapak Sabarudin dan anggota juganya juga sering dipesan 
oleh masyarakat sekitar yang mengadakan hajatan.

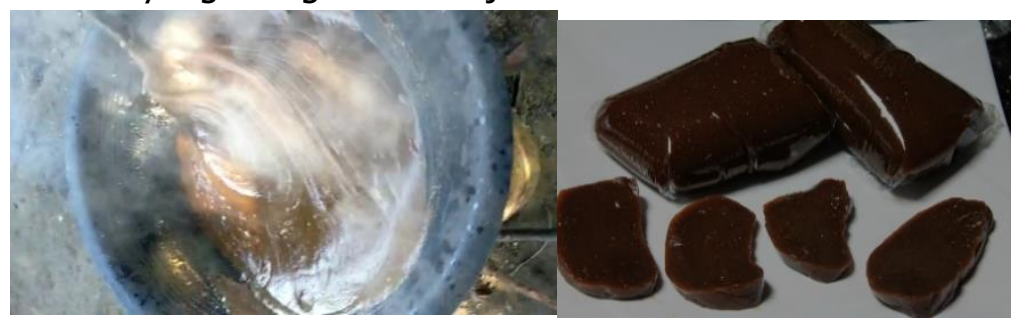

Gambar 2. Pembuatan Dodol dan Hasil Sumber: Dokumen Pribadi

Melalui pengabdian ini diberikan pelatihan tentang pembuatan media promosi dalam bentuk video promosi. Perkembangan teknologi informasi saat ini, banyak usaha yang dipromosikan menggunakan video. Promosi menggunakan video di era saat ini sangat efisien baik dari biaya maupun waktu. Dengan demikian, diharapkan dapat menjangkau khalayak konsumen lebih jauh jika video tersebut di publish ke media sosial seperti Facebook, Instagram dan media internet lainnya. Untuk membuat video promosi diambil dari gambar proses pembuatan dodol dari proses pemerasan santan, mengaduk bahan-bahan pembuatan dodol, proses mengaduk dodol, sampai hasil jadi. Setelah video promosi dibuat diharapkan dapat membantu menaikkan produksi penjualan dodol yang dilakukan oleh Bapak Sabarudin dan anggota agar lebih mudah dan ringan.

Hasil gambar maupun video yang sudah diambil diedit menggunakan software editing video. Software editing video yang digunakan adalah Filmora. Dengan demikian, pelatihan pembuatan video promosi ini diharapkan dapat diterapkan dan memotivasi Bapak Sabarudin dan anggotanya untuk membuat video promosi dodol untuk selanjutnya. Berdasarkan hasil identifikasi selama pelatihan pembuatan video promosi penjualan dodol ini menunjukkan bahwa masih kurangnya pemahaman Bapak Sabarudin dan anggotanya terhadap media promosi.

Adapun tahapan editing video dilakukan dengan membuka terlebih dahulu software editing yang digunakan. Lalu mengimpor seluruh hasil rekaman video maupun gambar yang sudah diambil sebelimnya ke dalam time line software Filmora. Setelah semua bahan di import ke dalam time line maka tahapan selanjutnya melakukan proses editing. Proses editing dilakukan agar bahan mentah yang masih berbentuk video dan gambar dapat menjadi sebuah kesatuan utuh. Dengan demikian diharapkan dapat menyampaikan informasi kepada konsumen tentang dodol yang diproduksi oleh Bapak Sabarudin dan anggotanya. Adapun time line software Filmora terlihat seperti gambar dibawah ini.

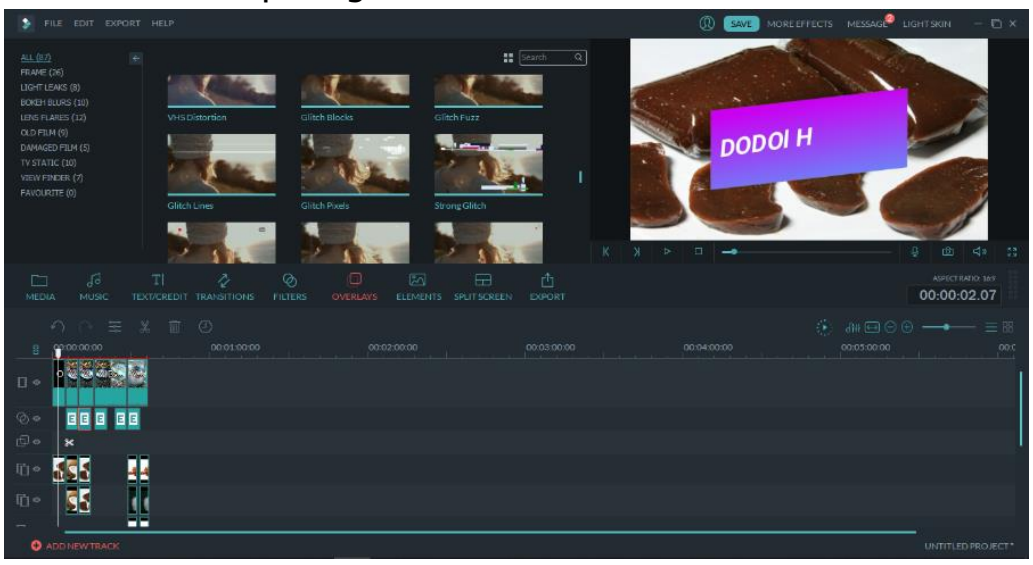


Gambar 3. Proses Editing Pembuatan Video Promosi Sumber: Capture Time Line Filmora

Pada gambar diatas terlihat susunan potongan video maupun gambar yang akan di edit menjadi sebuah video promosi yang utuh. Tahapan dilakukan dengan memilah potongan video dan gambar yang akan digunakan dan disusun menjadi sebuah video yang utuh agar informasi seputar dodol bapak Sabarudin bisa tersampaikan dengan baik melalui media video promosi. Setelah potongan video dan gambar disusun dengan sebaik mungkin dilakukan penambahan teks, suara, efek, dan lainnya. Tujuan penambahan hal tersebut agar video promosi dodol Bapak Sabarudin dan anggotanya memiliki nilai estetis. Adapun hasil akhir seperti terlihat pada potongan gambar dibawh ini.

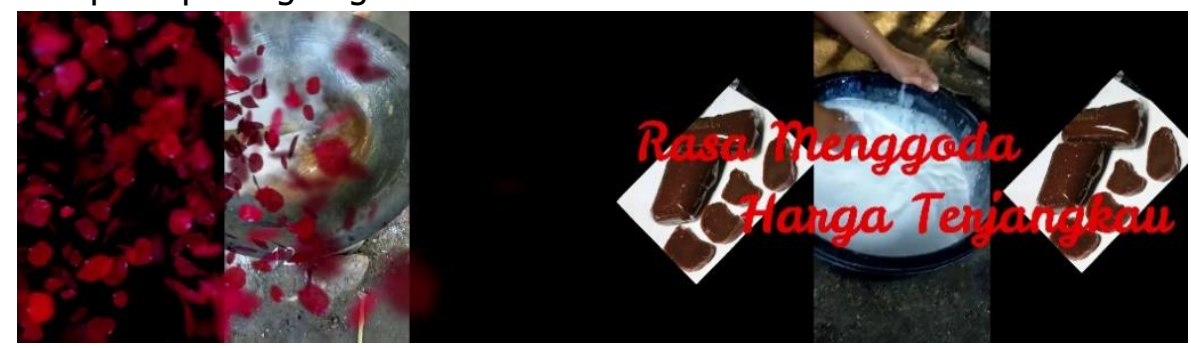

Gambar 4. Hasil Editing Video Promosi Dodol Sumber: Capture Time Line Filmora

Pada gambar diatas terlihat potongan video promosi dodol Bapak Sabarudin yang sudah dirender. Proses render dilakukan ketika semua potongan video, gambar, backsound musik, efek, dan sebagainya sudah disusun berdasarkan kebutuhan. Hasil video yang sudah dirender dapat digunakan untuk promosi dodol yang diproduksi. Teknik promosi dari mulut ke mulut bisa ditambah dengan promosi melalui media digital dengan adanya video promosi yang sudah dibuat.

\section{SIMPULAN}

Simpulan dalam kegiatan pengabdian kepada masyarakat yang penulis lakukan pada pelatihan pembuatan media video promosi penjualan dodol di Kecamatan Hamparan Perak Desa Lama yaitu telah mendapatkan peningkatan serta pengetahuan dan keterampilan terhadap penggunaan software editing terhadap pembuatan video promosi penjualan dodol, sehingga diharapkan jumlah produksi pesanan dodol dapat semakin meningkat.

\section{UCAPAN TERIMA KASIH}

Penulis mengucapkan terimakasih kepada Lembaga Pengabdian Pada Masyarakat Universitas Potensi Utama terhadap pendanaan dalam kegiatan ini. Tak lupa penulis juga mengucapkan kepada terimakasih kepada Bapak Sabarudin selaku pemilik usaha dodol dalam memberikan waktu luang untuk penulis dalam melihat proses pembuatan dodol hingga selesai. Dan kepada masyarakat Desa Lama Hamparan Perak penulis juga mengucapkan terimakasih atas partisipasi dan membantu dalam kegiatan ini sehingga kegiatan pengabdian masyarakat dapat berjalan dengan lancar. 


\section{REFERENSI}

Fathoni, A. (2006). Metodologi penelitian dan teknik penyusunan skripsi. Jakarta: Rineka Cipta. Goenawan, J. C., Suwasono, A. A., \& Salamoon, D. K. (2013). Perancangan Video Promosi Pulau Bawean Beserta Media Pendukungnya. Jurnal DKV Adiwarna, 1(2), 9.

Haryadi, R. N., Rojali, A., Fauzan, M., \& others. (2021). Sosialisasi Penggunaan Online Shop berbasis Website di UMKM Cimanggis. Jurnal Pengabdian Masyarakat Madani (JPMM), $1(1), 10-16$.

Herlina, N., Husin, A., \& others. (2021). Produksi Dodol Di Desa Paya Perupuk, Kecamatan Tanjung Pura, Kabupaten Langkat. Talenta Conference Series: Local Wisdom, Social, and Arts (LWSA), 4(1).

Jamaludin, A. (2015). Pengaruh Promosi Online Dan Persepsi Harga Terhadap Keputusan Pembelian (Survei pada Pelanggan Aryka Shop di Kota Malang). Jurnal Administrasi Bisnis, 21(1).

Kurniawan, H., \& Wahyurini, O. D. (2017). Perancangan Video Promosi Pasar Seni Tradisional Kumbasari Sebagai Pusat Busana Khas Bali Di Denpasar. Jurnal Sains Dan Seni ITS, 5(2). Sudjana, N. (2020). Penelitian dan penilaian pendidikan. Sinar Baru Algensindo.

Swastha, B., \& others. (2005). Menejemen Pemasaran Modern.

Wasan, G. H., \& Sariningsih, A. (2021). Pelatihan Pemasaran Produk Usaha Mikro Kecil Dan Menengah (UMKM) Berbasis Digital di Kecamatan Citeureup. Jurnal Pengabdian Masyarakat Madani (JPMM), 1(1), 31-36. 